\title{
FDA new drug approvals in Q1 2018
}

The first quarter of the year saw two notable FDA approvals for HIV therapies. In early February, Gilead Sciences gained approval for its triple combination product Biktarvy, which brings together the novel HIV-1 integrase inhibitor bictegravir with the established dual nucleoside reverse transcriptase inhibitor (NRTI) backbone of emtricitabine and tenofovir alafenamide in a once-daily, oral tablet formulation. Biktarvy is set to be one of 2018's biggest launches and Gilead's largest growth driver, with forecast sales of more than US $\$ 5$ billion in 2022 (TABLE 1). It is expected to eventually overtake the current market leader, GlaxoSmithKline's Triumeq - a once-daily, single-pill combination of the integrase inhibitor dolutegravir and the NRTIs abacavir and lamivudine that had sales of $\$ 3.2$ billion in 2017 . This was followed in early March by the approval of Theratechnologies' ibalizumab (Trogarzo), which is the first approved HIV treatment with a new mechanism of action in over a decade. The monoclonal antibody (mAb) works by binding to CD4, blocking the primary receptor for HIV entry into host cells. It is now one of a few treatments available for heavily pretreated patients with HIV who have failed on other therapies.
There were also two approvals in the oncology area.The first, at the end of January, was for Novartis's Lutathera, a somatostatin analogue labelled with the radiopharmaceutical lutetium-177. It was approved to treat somatostatin-receptor-positive gastroenteropancreatic neuroendocrine tumours (GEP-NETs), a group of rare digestive tract tumours. Novartis gained the product through its $\sim \$ 3.9$ billion acquisition of Advanced Accelerator Applications, which was completed early this year. The second oncology approval, weeks earlier than expected in mid-February, was for Johnson \& Johnson's (J\&J's) androgen receptor inhibitor apalutamide (Erleada). It is the first marketed product for non-metastatic prostate cancer and should help J\&J fight off upcoming generic competition to its other prostate cancer drug, abiraterone (Zytiga), which last year had sales of $\$ 2.5$ billion.

Also in mid-February, Vertex Pharmaceuticals received approval for its third cystic fibrosis product, Symdeko. The therapy combines ivacaftor - a previously approved potentiator of the cystic fibrosis transmembrane regulator (CFTR) channel, which is dysfunctional in patients with cystic fibrosis - with tezacaftor, a CFTR corrector. The increased efficacy of the product compared with ivacaftor alone and the broader patient population it can be prescribed for, coupled with a lower side effect profile, means Symdeko is expected to become Vertex's best seller to date, at least before its triple combinations that are currently in phase III trials reach the market.

Finally, the approval of tildrakizumab (Ilumya), a mAb that is specific for interleukin (IL)-23, for the treatment of psoriasis marks a shift for Sun Pharmaceuticals from a purely generics company to one that will have a proprietary marketed product. However, Ilumya will be competing in a highly crowded market that includes J\&J's IL-23-specific mAb guselkumab (Tremfya), as well as several $\mathrm{mAbs}$ that target IL-17. It will also have to contend with competition from biosimilar versions of psoriasis mainstays such as etanercept (Enbrel) and infliximab (Remicade).

$$
\begin{array}{r}
\text { Lisa Urquhart is at EP Vantage, London, UK. } \\
\text { e-mail: lisau@epvantage.com } \\
\text { doi:10.1038/nrd.2018.61 } \\
\text { Published online } 27 \text { Apr } 2018
\end{array}
$$

\begin{tabular}{|c|c|c|c|c|c|}
\hline Drug (brand name) & Company & $\begin{array}{l}\text { Date of approval } \\
\text { (expedited; pathway) }\end{array}$ & Mechanism & Indication & $\begin{array}{l}2022 \text { worldwide } \\
\text { sales forecast }\end{array}$ \\
\hline $\begin{array}{l}\text { Lutetium Lu } 177 \text { dotatate } \\
\text { (Lutathera) }\end{array}$ & Novartis & $\begin{array}{l}26 \text { January (yes; fast } \\
\text { track) }\end{array}$ & $\begin{array}{l}\text { Somatostatin- } \\
\text { receptor-targeted } \\
\text { radiopharmaceutical }\end{array}$ & GEP-NETS & $\$ 612$ million \\
\hline $\begin{array}{l}\text { Bictegravir, emtricitabine } \\
\text { and tenofovir alafenamide } \\
\text { (Biktarvy) }\end{array}$ & Gilead Sciences & $\begin{array}{l}7 \text { February (yes; priority } \\
\text { review) }\end{array}$ & $\begin{array}{l}\text { HIV-1 integrase } \\
\text { inhibitor; HIV-1 NRTIs }\end{array}$ & HIV treatment & $\$ 5,269$ million \\
\hline Apalutamide (Erleada) & Johnson \& Johnson & $\begin{array}{l}14 \text { February (yes; } \\
\text { priority review) }\end{array}$ & $\begin{array}{l}\text { Androgen receptor } \\
\text { inhibitor }\end{array}$ & Prostate cancer & $\$ 1,465$ million \\
\hline Ibalizumab (Trogarzo) & Theratechnologies & $\begin{array}{l}6 \text { March (yes; fast track } \\
\text { and breakthrough } \\
\text { therapy designation) }\end{array}$ & CD4 antibody & HIV treatment & $\$ 452$ million \\
\hline
\end{tabular}

Competing interests

The author declares no competing interests.

Table 1 | Selected FDA new drug approvals in Q1 2018

The table includes new drugs that are classified as new molecular entities or new therapeutic biologics approved by the FDA's Center for Drug Evaluation and Research (CDER). CFTR, cystic fibrosis transmembrane regulator; GEP-NETs, gastroenteropancreatic neuroendocrine tumours; IL, interleukin; NA, not applicable; NRTI, nucleoside reverse transcriptase inhibitor. Source: Evaluate Ltd, April 2018. 